Article

\title{
Synthesis, Characterization and Antiproliferative Evaluation of Pt(II) and Pd(II) Complexes with a Thiazine-Pyridine Derivative Ligand ${ }^{\dagger}$
}

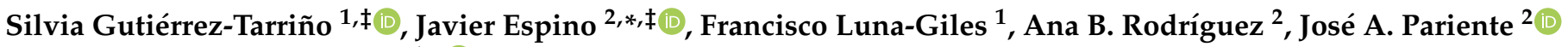 \\ and Emilio Viñuelas-Zahínos ${ }^{1, *(D)}$ \\ 1 Coordination Chemistry Research Group, Department of Organic and Inorganic Chemistry, Faculty of Science, \\ University of Extremadura, 06006 Badajoz, Spain; silgutar@doctor.upv.es (S.G.-T.); pacoluna@unex.es (F.L.-G.) \\ 2 Neuroimmunophysiology and Chrononutrition Research Group, Department of Physiology, Faculty of \\ Science, University of Extremadura, 06006 Badajoz, Spain; moratino@unex.es (A.B.R.); \\ pariente@unex.es (J.A.P.) \\ * Correspondence: jespino@unex.es (J.E.); emilvin@unex.es (E.V.-Z.); Tel.: +34-924289796 (J.E.); \\ +34-924289395 (E.V.-Z.) \\ + This Manuscript Is in Memoriam of Álvaro Bernalte García, Group Leader of the Coordination Chemistry \\ Research Group. \\ $\ddagger$ Both authors contributed equally.
}

Citation: Gutiérrez-Tarriño, S.; Espino, J.; Luna-Giles, F.; Rodríguez, A.B.; Pariente, J.A.; Viñuelas-Zahínos, E. Synthesis, Characterization and Antiproliferative Evaluation of $\mathrm{Pt}(\mathrm{II})$ and $\mathrm{Pd}(\mathrm{II})$ Complexes with a

Thiazine-Pyridine Derivative Ligand Pharmaceuticals 2021, 14, 395. https:// doi.org/10.3390/ph14050395

Academic Editors: Mary Meegan,

Guido Crisponi and

Alicia Dominguez-Martin

Received: 25 February 2021

Accepted: 20 April 2021

Published: 22 April 2021

Publisher's Note: MDPI stays neutral with regard to jurisdictional claims in published maps and institutional affiliations.

Copyright: (c) 2021 by the authors. Licensee MDPI, Basel, Switzerland. This article is an open access article distributed under the terms and conditions of the Creative Commons Attribution (CC BY) license (https:// creativecommons.org/licenses/by/ $4.0 /)$.

\begin{abstract}
Chemical, pharmacological, and clinical research on anticancer coordination complexes has led to noteworthy anticancer drugs such as cisplatin, carboplatin and oxaliplatin. Although these compounds are effective chemotherapeutic agents in the treatment of different tumors, they are associated with high toxicity and numerous side effects. Several studies have shown that the range of platinum complexes with antitumor activity is not limited to structural analogs of cisplatin. Therefore, the development of convenient anticancer drugs that can be effectively used for the treatment of human tumors has become the main goal of most research groups in this field. In this sense, active platinum complexes without NH groups, transplatinum complexes, multinuclear complexes, cationic complexes, and several classes of palladium(II) complexes have emerged. Herein, the synthesis and characterization of two Pt(II) or Pd(II) complexes with PyTz (2-(2-pyridyl)iminotetrahydro-1,3thiazine), a thiazine derivative ligand, with the formula $\left[\mathrm{MCl}_{2}(\mathrm{PyTz})\right] \cdot \mathrm{C}_{2} \mathrm{H}_{6} \mathrm{O}(\mathrm{M}=\mathrm{Pt}(\mathrm{II})$ or $\mathrm{Pd}(\mathrm{II}))$ were reported. The potential anticancer ability of both complexes was evaluated in epithelial cervix carcinoma HeLa, human ovary adenocarcinoma SK-OV-3, human histiocytic lymphoma U-937, and human promyelocytic leukemia HL-60 cell lines. Interestingly, the Pt(II) complex showed great cytotoxic potential against all tumor cell lines tested, whereas the $\mathrm{Pd}(\mathrm{II})$ complex displayed slight antitumor actions.
\end{abstract}

Keywords: Pd(II) and Pt(II) complexes; thiazine; pyridine; cytotoxicity; tumor cells; U-937; HL-60; SK-OV-3; HeLa

\section{Introduction}

In the last few years, many promising advances have been achieved in the field of cancer treatment. However, the disease still widely affects humanity and remains to be the second leading cause of death after cardiovascular diseases [1]. A total of 8.8 million people died from cancer in 2015, and the number of new cases is expected to increase by approximately $70 \%$ over the next twenty years [2]. Therefore, it is necessary to keep investigating the design of novel antitumor agents and seek new approaches.

Cisplatin (cis-diamminedichloroplatinum(II)), approved in 1978 for clinical use, is one of the most widely used complexes in anticancer therapy together with secondgeneration Pt complexes such as carboplatin (diammine(1,1-cyclobutanedicarboxylato(2-)$\left.\mathrm{O}, \mathrm{O}^{\prime}\right)$ platinum(II)), approved in 1993, or oxaliplatin (cis-[(1R,2R)-1,2-cyclohexanediammine- 
$\left.\mathrm{N}, \mathrm{N}^{\prime}\right]\left[\right.$ oxalato(2-)-O, $\mathrm{O}^{\prime}$ ]platinum(II)), approved in 2002 [3]. The square-planar Pt(II) complexes are activated by slow hydrolysis of the anionic ligands and the corresponding cationic aquo complexes formed bind to DNA creating stable intrachain cross-links that block replication and/or prevent transcription [4].

Although cisplatin is used against several kinds of cancer, such as cervical, bladder, lung, neck and head cancers [5-7], the use and efficacy of this drug are limited because of the intrinsic and acquired cell resistance after extended treatment $[8,9]$, as well as due to a large number of side effects [10-12] such as nausea, vomiting, ototoxicity, neurotoxicity, hemolytic anemia, nephrotoxicity and electrolyte disturbance. Even though carboplatin and oxaliplatin were introduced to overcome the disadvantages of cisplatin, this has not been completely achieved [13], thus indicating that it is still necessary to develop new compounds to be used at lower therapeutic doses with milder toxicity.

In the last two decades, several research groups have focused on obtaining metalbased drugs with high anticancer activity and reduced side effects with respect to cisplatin and its analogues. The significant similarity between the coordination chemistry of $\mathrm{Pd}(\mathrm{II})$ and $\mathrm{Pt}(\mathrm{II})$ complexes has promoted studies on Pd(II) compounds as anticancer drugs [14,15]. The ligand exchange rate of $\mathrm{Pd}(\mathrm{II})$ complexes is about $10^{4}-10^{5}$ times faster than the one for $\mathrm{Pt}$ (II) analogues, but they present better solubility compared to $\mathrm{Pt}$ (II) complexes [15]. Previous works have reported that a correct selection of ligands is very important, since they play a key role in several issues such as reactivity, lipophilicity and stability [16]. In this sense, different $\mathrm{Pd}(\mathrm{II})$ complexes with promising antitumor activity have been reported [14,17-19].

Nowadays, new coordination complexes are obtained by adding bioactive ligands such as heterocycles containing $\mathrm{N}$ - and S-donor atoms in their structure. Among these heterocycles, thiazines are six-membered heterocycles containing a $\mathrm{N}$ atom and a $\mathrm{S}$ atom. Depending on the relative position of the two heteroatoms and the degree of oxidation of the ring system, a large number of isomeric structures are possible. Some thiazines are well known, but others are rare and appear only as intermediates. There are some compounds derived from thiazines, such as N-(5,6-dihydro-4H-1,3-thiazin-2-yl)benzamide bromohydrate, which shows a high cytotoxic activity on human leukemic cells [20]. Moreover, this compound has the advantage that it is not toxic to healthy lymphocytes. This cytotoxic activity is related to the inhibitory capacity of this compound on nitric oxide synthase (NOS), an enzyme that regulates endogenous NO synthesis, which has a modulatory character in apoptosis or cell death [20].

On the other hand, pyridine is one of the best-known heterocyclic nitrogen ligands, and its coordination chemistry has been studied in depth. In fact, the Cambridge Structural Database (CSD, Conquest Version V5.41, Aug2020) [21] lists around 150,000 coordination compounds between a metal and a pyridine ring, of which 5313 complexes bear a $\mathrm{Pt}(\mathrm{II})$ pyridine bond and 5757 present a Pd(II)-pyridine bond. It should be noted that a large number of these compounds show recognized antitumor activity both in vitro and in vivo. For example, picoplatin (cis-aminedichloro(2-methilpyridine)platinum(II)) has been evaluated in lung, colon, prostate and ovarian cancer cells, showing high efficiency and low toxicity [22], while trans-dichloro[2-(hydroxyalkyl)pyridine] palladium(II) complexes show activity against lung and colon cancer cells, as well as in sarcomas [14],

In this sense, the ligand 2-(2-pyridyl)iminotetrahydro-1,3-thiazine (PyTz), which contains a 1,3-thiazine ring and a pyridine ring in its structure and has been previously used in our group for the synthesis of several transition metal complexes [23-25], could be a promising ligand in the synthesis of $\mathrm{Pt}(\mathrm{II})$ and $\mathrm{Pd}(\mathrm{II})$ complexes with antitumor activity.

Therefore, in this work, the synthesis, structural characterization and evaluation of cytotoxic potential against four human tumor cells of $\mathrm{Pt}(\mathrm{II})$ and $\mathrm{Pd}(\mathrm{II})$ complexes with PyTz was carried out. Moreover, the crystal structure of 2-(2-pyridyl)iminotetrahydro1,3-thiazinehydrochloride-water $(1 / 2)\left(\mathrm{PyTzHCl} \cdot 2 \mathrm{H}_{2} \mathrm{O}\right)$, which has never been described in the literature, is presented herein. Likewise, it is reported that PyTz-containing Pt(II) complex is considerably more biologically active than its $\mathrm{Pd}(\mathrm{II})$ counterpart. 


\section{Results and Discussion}

\subsection{Crystal Structures}

The X-ray study revealed that the PyTz $\cdot \mathrm{HCl}$ crystals are made up of triclinic unit cells, each containing two chloride ions, two $\mathrm{PyTzH}^{+}$cations and four water molecules of crystallization. It could be therefore formulated as $\mathrm{PyTz} \cdot \mathrm{HCl} \cdot 2 \mathrm{H}_{2} \mathrm{O}$. A diagram of the molecular structure and the atom numbering system used is shown in Figure 1a. Selected bond lengths, angles and hydrogen-bond parameters are listed in Table 1.

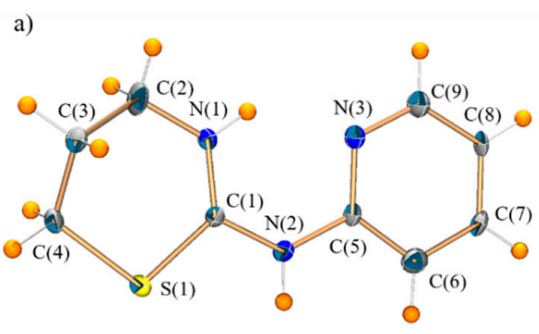

b)

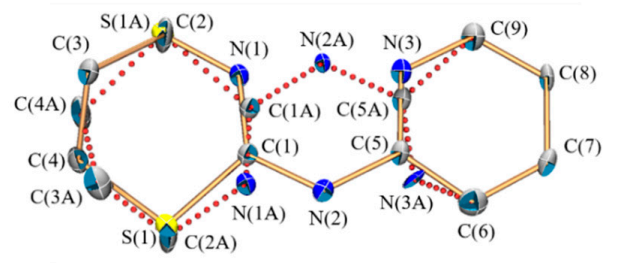

Figure 1. (a) Crystal structure and numbering system of majority arrangement for $\mathrm{PyTzHCl} \cdot 2 \mathrm{H}_{2} \mathrm{O}$, (b) Resolution of static disorder in the crystal structure and numbering system for $\mathrm{PyTzHCl} \cdot 2 \mathrm{H}_{2} \mathrm{O}$.

Table 1. Selected bond lengths $(\AA)$, angles $\left(^{\circ}\right)$ and hydrogen-bond parameters for $\mathrm{PyTzHCl} \cdot 2 \mathrm{H}_{2} \mathrm{O}$.

\begin{tabular}{cccc}
\hline $\mathrm{S}(1)-\mathrm{C}(1)$ & $1.744(2)$ & $\mathrm{S}(1 \mathrm{~A})-\mathrm{C}(1 \mathrm{~A})$ & $1.873(6)$ \\
\hline $\mathrm{C}(1)-\mathrm{N}(1)$ & $1.302(2)$ & $\mathrm{C}(1 \mathrm{~A})-\mathrm{N}(1 \mathrm{~A})$ & $1.229(8)$ \\
$\mathrm{C}(1)-\mathrm{N}(2)$ & $1.355(2)$ & $\mathrm{C}(1 \mathrm{~A})-\mathrm{N}(2 \mathrm{~A})$ & $1.408(5)$ \\
$\mathrm{N}(1)-\mathrm{C}(2)$ & $1.396(7)$ & $\mathrm{N}(1 \mathrm{~A})-\mathrm{C}(2 \mathrm{~A})$ & $1.558(7)$ \\
$\mathrm{N}(2)-\mathrm{C}(5)$ & $1.401(2)$ & $\mathrm{N}(2 \mathrm{~A})-\mathrm{C}(5 \mathrm{~A})$ & $1.415(9)$ \\
$\mathrm{N}(3)-\mathrm{C}(5)$ & $1.328(2)$ & $\mathrm{N}(3 \mathrm{~A})-\mathrm{C}(5 \mathrm{~A})$ & $1.312(12)$ \\
$\mathrm{N}(3)-\mathrm{C}(9)$ & $1.322(2)$ & $\mathrm{C}(9)-\mathrm{C}(8)$ & $1.382(2)$ \\
$\mathrm{S}(1)-\mathrm{C}(1)-\mathrm{N}(1)$ & $125.5(1)$ & $\mathrm{S}(1 \mathrm{~A})-\mathrm{C}(1 \mathrm{~A})-\mathrm{N}(1 \mathrm{~A})$ & $128.4(3)$ \\
$\mathrm{N}(1)-\mathrm{C}(1)-\mathrm{N}(2)$ & $122.0(1)$ & $\mathrm{N}(1 \mathrm{~A})-\mathrm{C}(1 \mathrm{~A})-\mathrm{N}(2 \mathrm{~A})$ & $124.7(4)$ \\
$\mathrm{N}(2)-\mathrm{C}(5)-\mathrm{N}(3)$ & $118.4(1)$ & $\mathrm{N}(2 \mathrm{~A})-\mathrm{C}(5 \mathrm{~A})-\mathrm{N}(3 \mathrm{~A})$ & $121.1(7)$ \\
$\mathrm{N}(3)-\mathrm{C}(5)-\mathrm{C}(6)$ & $122.9(1)$ & $\mathrm{C}(5 \mathrm{~A})-\mathrm{N}(3 \mathrm{~A})-\mathrm{C}(6)$ & $119.5(7)$ \\
\hline $\mathrm{D}-\mathrm{H} \cdots \mathrm{A}$ & $\mathrm{A} \mathrm{position}$ & $\mathrm{D} \cdots \mathrm{A}(\mathrm{A})$ & $\left.\mathrm{D}-\mathrm{H} \cdots \mathrm{A} \mathbf{(}^{\circ}\right)$ \\
\hline $\mathrm{N}(2)-\mathrm{H}(2) \cdots \mathrm{O}(2 \mathrm{~W})$ & $\mathrm{x}, \mathrm{y}, \mathrm{z}$ & $2.701(2)$ & $168.7(1)$ \\
$\mathrm{N}(1)-\mathrm{H}(1) \cdots \mathrm{N}(3)$ & $\mathrm{x}, \mathrm{y}, \mathrm{z}$ & $2.647(2)$ & $133.7(1)$ \\
$\mathrm{O}(2 \mathrm{~W})-\mathrm{H}(4 \mathrm{~W}) \cdots \mathrm{O}(1 \mathrm{~W})$ & $\mathrm{x}, \mathrm{y}, \mathrm{z}$ & $2.761(2)$ & $173.6(2)$ \\
$\mathrm{O}(2 \mathrm{~W})-\mathrm{H}(3 \mathrm{~W}) \cdots \mathrm{Cl}(1)$ & $-\mathrm{x},-\mathrm{y}+1,-\mathrm{z}+1$ & $3.177(1)$ & $173.9(2)$ \\
$\mathrm{O}(1 \mathrm{~W})-\mathrm{H}(2 \mathrm{~W}) \cdots \mathrm{Cl}(1)$ & $\mathrm{x},-\mathrm{y}-1,+\mathrm{z}-1$ & $3.162(1)$ & $173.5(1)$ \\
$\mathrm{O}(1 \mathrm{~W})-\mathrm{H}(1 \mathrm{~W}) \cdots \mathrm{Cl}(1)$ & $-\mathrm{x}+1,-\mathrm{y}+1,-\mathrm{z}+1$ & $3.209(1)$ & $171.8(2)$ \\
\hline
\end{tabular}

In the electronic density map obtained in the resolution of the crystalline structure, it was possible to verify that the atoms of the organic cation were involved in a static disorder and, consequently, they were modeled using two sets of positions, for which a normal numbering system was used for the atoms of one of the arrangements and the letter A was added to those of the other (Figure 1b). However, it was not possible to model all the atoms of arrangement A because some of them almost matched in space with some atoms of the pyridine ring and, in addition, this led to an invalid model in which the pyridine was not flat. In this sense, the occupancy of the two alternative orientations was restricted to the unit by calculating the occupancy factors, which were found to be $0.82(1)$ for the numbered orientation and 0.18(1) for the orientation named as A.

For this compound, as can be observed in Table 1, the endocyclic bond $\mathrm{C}(1)-\mathrm{N}(1)$ length [1.302(2) $\AA]$ is similar to the one of the exocyclic bond C(1)-N(2) [1.355(2) $\AA]$, both being between $\mathrm{C}=\mathrm{N}[1.26 \AA]$ and $\mathrm{C}-\mathrm{N}[1.47 \AA]$ [7]. It can also be observed that the length $\mathrm{C}(1)-\mathrm{S}(1)[1.744(2) \AA]$ is smaller than the length $\mathrm{C}(4)-\mathrm{S}(1)[1.806(2) \AA]$ and it is between $\mathrm{C}=\mathrm{S}$ $(1.61 \AA)$ and C-S (1.82 ̊̊) [26]. On the other hand, bond angles in which the N(1), C(1), N(2) 
and S(1) atoms are involved showed that the hybridization adopted for the first three is $\sim \mathrm{sp}^{2}$, while sulfur uses $\sim \mathrm{p}$ orbitals to build the $\sigma$ structure. Moreover, all these atoms are coplanar. This information indicates the presence of an extended multiple bond around the $\mathrm{C}(1)$ atom. These remarks, together with the presence of a hydrogen atom linked to N(1), support the fact that the predominant tautomeric form is the iminotetrahydro-1,3-thiazine form instead of the amino-5,6-dihydro-4H-1,3-thiazine form, for which a shorter exocyclic $\mathrm{C}-\mathrm{N}$ bond length and a significantly longer endocyclic $\mathrm{C}-\mathrm{N}$ distance would be expected.

Interestingly, as can be seen in Figure 2a, the crystal is stabilized by an intermolecular hydrogen bond system in which each chloride ion behaves like a hydrogen acceptor, $\mathrm{N}(2)$ atom as a hydrogen donator and water behaves in both ways.

a)

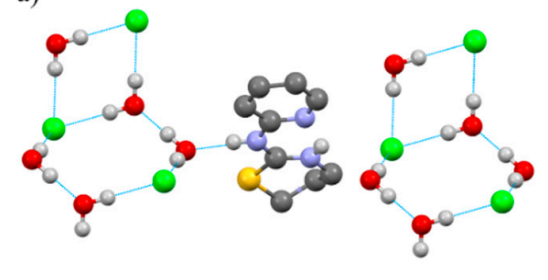

b)

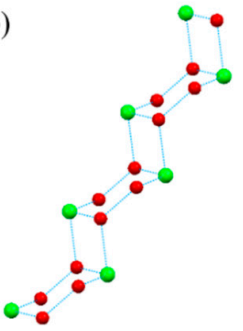

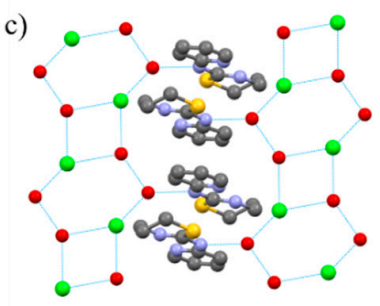

Figure 2. (a) Intermolecular hydrogen bond system in the crystal structure of $\mathrm{PyTzHCl}_{2} 2 \mathrm{H}_{2} \mathrm{O}$. (b) Conformation of $\left\{\left[\left(\mathrm{H}_{2} \mathrm{O}\right)_{5} \mathrm{Cl}_{3}\right]^{3-}\right\}_{n}$ tapes in the PyTzHCl$\cdot 2 \mathrm{H}_{2} \mathrm{O}$ crystal structure. (c) Supramolecular structure of $\mathrm{PyTzHCl} \cdot 2 \mathrm{H}_{2} \mathrm{O}$.

In particular, the chloride ions and the water molecules create $\left\{\left[\left(\mathrm{H}_{2} \mathrm{O}\right)_{5} \mathrm{Cl}_{3}\right]^{3-}\right\}_{n}$ tapes, whose structural parameters are summarized in Figure S1. In these tapes, the planar $\left[\left(\mathrm{H}_{2} \mathrm{O}\right)_{2} \mathrm{Cl}_{2}\right]^{2-}$ units are linked by two water molecules, creating staircase-like architectures running parallel to the $a$ axis (Figure 2b). Alternatively, they can be described as a periodic repetition of fused four-membered rings $\left(2 \mathrm{H}_{2} \mathrm{O}\right.$ and $\left.2 \mathrm{Cl}^{-}\right)$and six-membered rings $\left(4 \mathrm{H}_{2} \mathrm{O}\right.$ and $2 \mathrm{Cl}^{-}$) in the tape, which can be considered to come from the T4(2)6(2) water assembly with two $\mathrm{H}_{2} \mathrm{O}$ molecules from the hexagonal ring substituted by two chloride ions. The four-membered ring is planar but, in the $\left(\mathrm{H}_{2} \mathrm{O}\right)_{4} \mathrm{Cl}_{2}$ ring, two of the water molecules are found at $1.003 \AA$ away from the best least-squared plane, adopting a chair configuration (Figure $2 b$ ). Furthermore, the water molecules that link the planar $\left[\left(\mathrm{H}_{2} \mathrm{O}\right)_{2} \mathrm{Cl}_{2}\right]^{2-}$ units are hydrogen bonded to an $\mathrm{NH}$ fragment of an organic cation $\mathrm{PyTzH}^{+}$, these cations filling in the spaces formed between two chains (Figure 2c).

The crystal structures of metal complexes are made up of monomeric $\left[\mathrm{MCl}_{2}(\mathrm{PyTz})\right]$ molecules (Figure 3) and ethanol solvate molecules, therefore the compounds can be formulated as $\left[\mathrm{PtCl}_{2}(\mathrm{PyTz})\right] \cdot \mathrm{C}_{2} \mathrm{H}_{6} \mathrm{O}(\mathrm{PtPyTz})$ and $\left[\mathrm{PdCl}_{2}(\mathrm{PyTz})\right] \cdot \mathrm{C}_{2} \mathrm{H}_{6} \mathrm{O}(\mathrm{PdPyTz})$. As can be seen, PtPyTz and PdPyTz have the same coordination mode, with the metal center located in a slightly distorted square-planar coordination geometry (dihedral angles between planes $\mathrm{Cl}(1)-\mathrm{M}-\mathrm{Cl}(2)$ and $\mathrm{N}(1)-\mathrm{M}-\mathrm{N}(3)$ are $2.6^{\circ}$ in PtPyTz and $3.6^{\circ}$ in PdPyTz). This metal center is surrounded by one PyTz molecule, which behaves as a chelated bidentate ligand coordinated by one pyridinic nitrogen and one thiazinic nitrogen, thus forming a six-membered metallocycle with a near to boat configuration in both complexes. Two chlorine ions in cis disposition complete the coordination environment. 

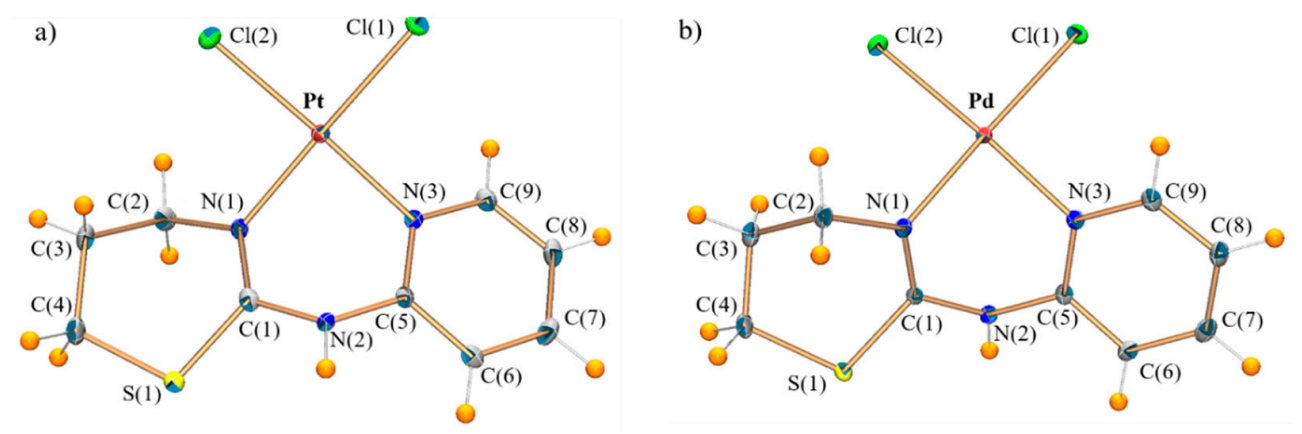

Figure 3. Crystal structures of (a) PtPyTz and (b) PdPyTz. Ethanol solvate is omitted for clarity.

As can be seen in Table 2, $\mathrm{M}-\mathrm{Cl}$ bond lengths in both complexes are similar to calculated mean values for squared-planar cis complexes with a $\mathrm{Cl}_{2} \mathrm{~N}_{2}$ coordination environment around M(II) ion (2.298(18) ^̊ for 620 Pt(II) complexes; 2.293(19) A for 879 Pd(II) complexes) obtained with CONQUEST software from the Cambridge Structural Database (CSD, Version V5.41, Aug2020) [21]. In the same way, the M- $\mathrm{N}_{\text {pyridine }}$ bond lengths are similar to the average value found for squared-planar complexes with $\mathrm{Cl}_{2} \mathrm{~N}_{2}$ coordination sphere around M(II) ion (2.020(23) $\AA$ for 315 Pt(II) complexes; 2.039(28) $\AA$ for 427 Pd(II) complexes) in CSD [21]. However, the Pt- $\mathrm{N}_{\text {thiazine }}$ bond distance is slightly shorter than the mean value calculated [2.091(32) $\AA$ ] for five crystal structures with this type of bond in CSD [21]. Finally, to our best knowledge, PdPyTz is the first crystal structure of a Pd(II) complex having a 1,3-thiazine link to Pd(II) in CSD [21].

Table 2. Selected bond lengths $(\AA)$, angles $\left(^{\circ}\right)$ and hydrogen-bond parameters for PtPyTz and PdPyTz.

\begin{tabular}{|c|c|c|c|c|}
\hline \multirow[t]{8}{*}{ PtPyTz } & $\mathrm{Pt}-\mathrm{Cl}(1)$ & $2.306(1)$ & $\mathrm{Pt}-\mathrm{Cl}(2)$ & 2.306 \\
\hline & Pt-N(1) & $2.013(2)$ & Pt-N(3) & $2.017(2)$ \\
\hline & $\mathrm{Cl}(1)-\mathrm{Pt}-\mathrm{Cl}(2)$ & $90.1(1)$ & $\mathrm{Cl}(1)-\mathrm{Pt}-\mathrm{N}(1)$ & $177.9(1)$ \\
\hline & $\mathrm{Cl}(1)-\mathrm{Pt}-\mathrm{N}(3)$ & $91.5(1)$ & $\mathrm{Cl}(2)-\mathrm{Pt}-\mathrm{N}(1)$ & $91.0(1)$ \\
\hline & $\mathrm{Cl}(2)-\mathrm{Pt}-\mathrm{N}(3)$ & 177.5(1) & $\mathrm{N}(1)-\mathrm{Pt}-\mathrm{N}(3)$ & $87.4(1)$ \\
\hline & D-H $\cdots A$ & A position & D...A (Å) & $\mathrm{D}-\mathrm{H} \cdots \mathbf{A}\left({ }^{\circ}\right)$ \\
\hline & $\mathrm{N}(2)-\mathrm{H}(2) \cdots \mathrm{O}$ & $x, y, z$ & $2.736(3)$ & $162.5(2)$ \\
\hline & $\mathrm{O}-\mathrm{H}(0) \cdots \mathrm{Cl}(2)$ & $x, y+1, z+1 / 2$ & $3.136(2)$ & 135.3(2) \\
\hline \multirow[t]{8}{*}{ PdPyTz } & $\mathrm{Pd}-\mathrm{Cl}(1)$ & $2.302(1)$ & $\mathrm{Pd}-\mathrm{Cl}(2)$ & $2.303(1)$ \\
\hline & Pd-N(1) & $2.016(1)$ & $\mathrm{Pd}-\mathrm{N}(3)$ & $2.021(1)$ \\
\hline & $\mathrm{Cl}(1)-\mathrm{Pd}-\mathrm{Cl}(2)$ & $90.6(2)$ & $\mathrm{Cl}(1)-\mathrm{Pd}-\mathrm{N}(1)$ & 177.7(2) \\
\hline & Cl(1)-Pd-N(3) & $91.5(1)$ & $\mathrm{Cl}(2)-\mathrm{Pd}-\mathrm{N}(1)$ & $90.8(1)$ \\
\hline & $\mathrm{Cl}(2)-\mathrm{Pd}-\mathrm{N}(3)$ & $176.2(1)$ & $\mathrm{N}(1)-\mathrm{Pd}-\mathrm{N}(3)$ & 87.1(1) \\
\hline & D-H...A & A position & 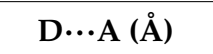 & $\mathrm{D}-\mathrm{H} \cdots \mathrm{A}\left({ }^{\circ}\right)$ \\
\hline & $\mathrm{N}(2)-\mathrm{H}(2) \cdots \mathrm{O}$ & $x, y, z$ & $2.744(2)$ & $175.8(2)$ \\
\hline & $\mathrm{O}-\mathrm{H}(0) \cdots \mathrm{Cl}(2)$ & $x, y-1, z$ & $3.180(3)$ & 162.1(1) \\
\hline
\end{tabular}

With respect to the supramolecular arrangement, the structure is stabilized by intramolecular hydrogen bonds between the oxygen atom from the ethanol and the hydrogen atom bonded to $\mathrm{N}(2)$, and between the $\mathrm{O}-\mathrm{H}$ of the ethanol and $\mathrm{Cl}(2)$, building chains along axis $b$ (Figures S2 and S3 for PtPyTz and PdPyTz, respectively).

\subsection{Spectroscopic Studies}

The ligand PyTz and its $\mathrm{Pt}(\mathrm{II})$ and $\mathrm{Pd}(\mathrm{II})$ complexes were studied by spectroscopic techniques such as NMR and IR. ${ }^{1} \mathrm{H}$ and ${ }^{13} \mathrm{C}$ NMR spectra of the ligand and both complexes are represented in Figures S4-S9 and the ${ }^{1} \mathrm{H}-\mathrm{NMR}$ spectral data for PyTz and its complexes are shown in Table S1. As can be observed, the signals in metal complexes are shifted downfield compared to those corresponding to the free ligand. These differences indicate that the organic ligand is coordinated to the metal center in the $\mathrm{N}, \mathrm{N}$-dimethylformamide 
(DMF) solution for both complexes. Moreover, both the ligand and the complexes were kept in solution for 25 days before being measured by NMR again, which shows the high stability of these complexes in the DMF medium. Finally, the stability of compounds in aqueous media was determined by ${ }^{1} \mathrm{H}-\mathrm{NMR}$ spectroscopy adding $0.55 \mathrm{~mL}$ of $\mathrm{D}_{2} \mathrm{O}$ at a $50 \mu \mathrm{L}$ of solution of the compound in DMF- $\mathrm{d}_{7}$. Spectra of compounds (Figures S10-S12) are identical after $24 \mathrm{~h}$ for PyTz and PdPyTz, which indicates that compounds stay unalterable. However, for PtPyTz the apparition of new signals, clearly after $6 \mathrm{~h}$, shows a certain degree of decomposition.

The IR spectra of complexes PtPyTz and PdPyTz (Figures S13-S16) showed several strong-medium $v(\mathrm{NH})$ absorption between 3262 and $3126 \mathrm{~cm}^{-1}$, while only a medium band at $3181 \mathrm{~cm}^{-1}$ was observed for the uncoordinated PyTz ligand. Moreover, a strong $v(\mathrm{C}=\mathrm{N})$ absorption (at $1631 \mathrm{~cm}^{-1}$ in PtPyTz and at $1629 \mathrm{~cm}^{-1}$ in PdPyTz) could be observed. These bands were shifted to higher wavenumbers relative to the imine function of the free ligand $\left(1593 \mathrm{~cm}^{-1}\right)$. Both facts could be correlated with the change of tautomeric form from iminotetrahydro-1,3-thiazine for the free ligand to the amino-5,6-dihydro- $4 \mathrm{H}-1,3$-thiazine when the ligand is coordinated to a metallic center. Likewise, the bands corresponding to the in-plane stretching vibrations of the pyridine ring were also shifted, in general, to lower wavenumbers compared with the ones of the uncoordinated ligand. Consequently, coordination via the nitrogen atom of the pyridine ring of the ligand can be deduced.

In the low-frequency region, the $\mathrm{C} 1$ symmetry of $\mathrm{Pt}(\mathrm{II})$ and $\mathrm{Pd}$ (II) complexes predicted the appearance of four bands assignable to metal-ligand stretching vibrations, $v(\mathrm{M}$-ligand) in IR $[27,28]$. However, for cis complexes, it could be expected two vibrations $v(\mathrm{M}-\mathrm{Cl})$ corresponding to symmetric and asymmetric stretching mode $\left(314\right.$ and $328 \mathrm{~cm}^{-1}$ for PtPyTz, 323 and $330 \mathrm{~cm}^{-1}$ for PdPyTz) [29-33]. Likewise, in this type of complexes, two bands for each vibration $v(\mathrm{M}-\mathrm{N})$ are expected, although it can be normally only observed one of them. In this case, the bands which appeared at 259 and $252 \mathrm{~cm}^{-1}$ in PtPyTz and at $254 \mathrm{~cm}^{-1}$ in PdPyTz spectra were attributed to $v\left(\mathrm{M}-\mathrm{N}_{\text {pyridine }}\right)$ vibrations [29], while the bands detected at 243 and $232 \mathrm{~cm}^{-1}$ in PtPyTz and at 242 and $233 \mathrm{~cm}^{-1}$ in PdPyTz were assigned to $v\left(\mathrm{M}-\mathrm{N}_{\text {thiazine }}\right)$ vibrations $[23,24]$.

\subsection{In Silico ADME Prediction}

The SwissADME web tool was used to compute physiochemical properties and the Absorption, Distribution, Metabolism, and Excretion (ADME) parameters [34]. From this computation, the pharmacokinetics and drug-likeness of compounds were predicted. The obtained results are presented in Table S2. It should be noted that the compounds were evaluated according to Lipinski's rule of five [35] and PAINS alerts [36], having zero violations or alerts. When compared to the allowed values for polarity (TPSA $\leq 140 \AA^{2}$ ), lipophilicity $\left(\log \mathrm{P}_{\mathrm{o} / \mathrm{w}}<5\right)$, solubility $(\log \mathrm{s} \geq-6)$, size $\left(\mathrm{M}_{\mathrm{w}} \leq 500 \mathrm{~g} / \mathrm{mol}\right)$ and flexibility (number of rotable bonds $\leq 9$ ), all compounds show calculated values within these ranges. Finally, compounds showed a high gastrointestinal absorption potential and blood-brain barrier crossing ability. These results lead to the conclusion that the investigated compounds could be good candidates as anticancer drugs.

\subsection{Biological Activity}

Finally, the cytotoxic potential of the ligand PyTz and its $\mathrm{Pt}(\mathrm{II})$ and $\mathrm{Pd}(\mathrm{II})$ complexes was evaluated against four selected human tumor cell lines, namely U-937 histiocytic lymphoma, HL-60 promyelocytic leukemia, HeLa epithelial cervix carcinoma, and SK-OV3 ovary adenocarcinoma cells (Figure 4 ). 

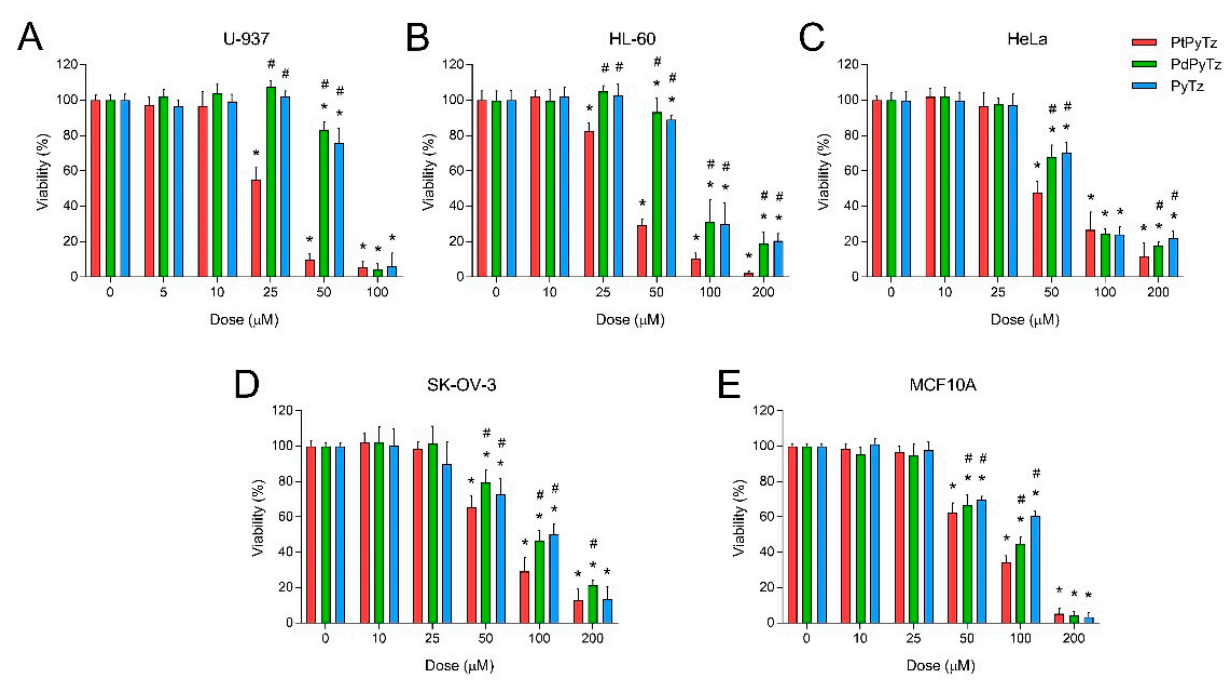

Figure 4. Dose-response curves of chemotherapeutics on cell viability of tumor and non-tumor cell lines. (A) U-937, (B) HL-60, (C) HeLa, (D) SK-OV-3 and (E) MCF10A cells were treated for $24 \mathrm{~h}$ with increasing concentrations $(5,10,25,50,100$ and $200 \mu \mathrm{M}$, as indicated) of the ligand PyTz, the Pt(II) (PtPyTz) and Pd(II) (PdPyTz) complexes, or the vehicle (DMF, control). Data represent means \pm S.D. of six independent experiments and are expressed as a percentage of control values. ${ }^{*} p<0.05$ compared to their corresponding control values. ${ }^{\#} p<0.05$ compared to their corresponding PtPyTz values.

The Pt(II) complex PtPyTz proved to be more promising as an anticancer drug since it depicted great cytotoxic potential against all tumor cell lines tested (Figure 4). The $\mathrm{Pt}(\mathrm{II})$ complex was more selective towards leukemic cell lines U-937 and HL-60 (IC 50 values were $26.36 \pm 2.56 \mu \mathrm{M}$ and $39.25 \pm 3.86 \mu \mathrm{M}$, respectively; Table 3 ), and a bit less efficient against solid tumor cell lines HeLa and SK-OV-3 $\left(\mathrm{IC}_{50}\right.$ values were $63.38 \pm 5.63 \mu \mathrm{M}$ and $77.97 \pm 6.36 \mu \mathrm{M}$, respectively; Table 3). On the contrary, the Pd(II) complex PdPyTz showed low cytotoxic potential, the most remarkable cell killing ability being displayed against HeLa cells ( $\mathrm{IC}_{50}$ values were $78.62 \pm 8.21 \mu \mathrm{M}$; Table 3 and Figure 4$)$. The effect of the ligand PyTz was comparable to that of PdPyTz in all four tumor cell lines (Figure 4 and Table 3), which confirms the slight antitumor actions of the Pd(II) complex. Likewise, both PtPyTz and PdPyTz showed moderate toxicity against epithelial non-tumor MCF10A cell line ( $\mathrm{IC}_{50}$ values were $75.94 \pm 7.74 \mu \mathrm{M}$ and $81.54 \pm 8.29 \mu \mathrm{M}$, respectively; Table 3 and Figure 4); however, the effective doses of $\mathrm{Pt}(\mathrm{II})$ complex, especially those against leukemic cell lines U-937 and HL-60 (26.36 and $39.25 \mu \mathrm{M}$, respectively), had negligible effects on cell viability of MCF10A epithelial cells. In any case, the standard chemotherapeutic agent cisplatin exhibited lower $\mathrm{IC}_{50}$ values than the PyTz-containing complexes towards the four tumor cell lines (Table 3), although it also showed higher toxicity against MCF10A nontumor cells (Table 3). The fact that $\mathrm{Pt}(\mathrm{II})$ complexes are considerably more active than their $\mathrm{Pd}(\mathrm{II})$ counterparts has been previously reported for different organometallic compounds, such as pyrazole-based complexes [37] and complexes with tertiary arsenic ligands [38]. Nonetheless, other studies have reported Pd(II) complexes with both superior [39] and similar $[2,40]$ biological activity to that of analogue $\mathrm{Pt}(\mathrm{II})$ complexes, thereby suggesting that the cytotoxic effect can be modulated by either the central metal or the ligand (the former being the case in the present study). 
Table 3. Cytotoxicity (IC50 $\pm \mathrm{SD}, \mu \mathrm{M}$ ) of the free ligand $\mathrm{PyTz}$ and their $\mathrm{Pt}(\mathrm{II})$ and $\mathrm{Pd}(\mathrm{II})$ complexes towards selected tumor and healthy (non-tumor) cell lines.

\begin{tabular}{cccccc}
\hline & U-937 & HL-60 & HeLa & SK-OV-3 & MCF10A \\
\hline PtPyTz & $26.36 \pm 2.56^{\mathrm{b}}$ & $39.25 \pm 3.86^{\mathrm{b}}$ & $63.38 \pm 5.63^{\mathrm{b}}$ & $77.97 \pm 6.36^{\mathrm{b}}$ & $75.94 \pm 7.74^{\mathrm{b}}$ \\
PdPyTz & $90.96 \pm 17.66^{\mathrm{c}}$ & $115.20 \pm 17.01^{\mathrm{c}}$ & $78.62 \pm 8.21^{\mathrm{c}}$ & $117.20 \pm 11.69^{\mathrm{c}}$ & $81.54 \pm 8.29^{\mathrm{c}}$ \\
PyTz & $79.42 \pm 14.64^{\mathrm{c}}$ & $107.10 \pm 15.78^{\mathrm{c}}$ & $82.31 \pm 9.41^{\mathrm{c}}$ & $97.32 \pm 10.05^{\mathrm{c}}$ & $101.70 \pm 2.00^{\mathrm{d}}$ \\
Cisplatin & $7.89 \pm 0.54^{\mathrm{a}}$ & $11.32 \pm 1.04^{\mathrm{a}}$ & $16.08 \pm 1.01^{\mathrm{a}}$ & $55.41 \pm 3.04^{\mathrm{a}}$ & $50.34 \pm 5.16^{\mathrm{a}}$ \\
\hline
\end{tabular}

Within each column, values followed by the same lowercase letter are not significantly different $(p<0.05$; Tukey's test).

\section{Materials and Methods}

\subsection{General Procedures}

Human epithelial cervix carcinoma HeLa cell line (No. 93021013), human ovary adenocarcinoma SK-OV-3 cell line (No. 91091004), human histiocytic lymphoma U-937 cell line (No. 85011440), and human promyelocytic leukemia HL-60 15-12 cell line (No. 88120805) were purchased from the European Collection of Authenticated Cell Cultures (ECACC) (Dorset, U.K.). Human non-tumorigenic epithelial MCF10A cell line (No. CRL-10317) was obtained from the American Type Culture Collection (ATCC) (Barcelona, Spain). RPMI-1640, McCoy's 5a, Dulbecco's modified Eagle's medium (DMEM), DMEM F-12, penicillin/streptomycin, foetal bovine serum (FBS), horse serum and L-glutamine were procured from ThermoFisher Scientific (Barcelona, Spain). Hydrocortisone, insulin, epidermal growth factor (EGF) and cholera toxin were bought from Sigma (Madrid, Spain). CellTiter 96 AQueous One Solution Cell Proliferation Assay was acquired from Promega (Madrid, Spain). All reagents and solvents were purchased from commercial suppliers and used without further purification.

On the other hand, 2-(2-pyridyl)iminotetrahydro-1,3-thiazinehydrochloride-water (1/2) $\left(\mathrm{PyTzHCl} \cdot 2 \mathrm{H}_{2} \mathrm{O}\right)$, the ligand 2-(2-pyridyl)iminotetrahydro-1,3-thiazine (PyTz) [24] and the precursor $\left[\mathrm{PtCl}_{2}(\mathrm{DMSO})_{2}\right]$ [41] were prepared as described in the literature.

Isolated compounds were characterized by elemental analysis, ${ }^{1} \mathrm{H}-\mathrm{NMR},{ }^{13} \mathrm{C}-\mathrm{NMR}$, FTIR and single-crystal X-ray diffraction. When available, characterization given in the literature was used for comparison. Chemical analysis of carbon, hydrogen, nitrogen and sulphur were performed by microanalytical methods using a Leco CHNS-932 analyzer. IR spectra were recorded on a Perkin-Elmer Spectrum 100 FTIR spectrophotometer, from $\mathrm{KBr}$ pellets in the $4000-400 \mathrm{~cm}^{-1}$ range, and on a Perkin-Elmer FTIR 1700X spectrophotometer, from Nujol mulls in the $500-150 \mathrm{~cm}^{-1}$ range. ${ }^{1} \mathrm{H},{ }^{13} \mathrm{C}$ NMR spectra were obtained with a Bruker Advance III 500 instrument at $500 \mathrm{MHz}$ in DMF- $\mathrm{d}_{7} .{ }^{1} \mathrm{H}$ NMR signals were referenced to residual proton resonances in deuterated solvents.

\subsection{Synthesis of $\left[\mathrm{PtCl}_{2}(\mathrm{PyTz})\right] \cdot \mathrm{C}_{2} \mathrm{H}_{6} \mathrm{O}$ (PtPyTz)}

A solution of PyTz $(96.5 \mathrm{mg}, 0.5 \mathrm{mmol})$ in ethanol $(30 \mathrm{~mL})$ was added dropwise to a solution of $\left[\mathrm{PtCl}_{2}(\mathrm{DMSO})_{2}\right](211 \mathrm{mg}, 0.5 \mathrm{mmol})$ in ethanol $(40 \mathrm{~mL})$ at $50{ }^{\circ} \mathrm{C}$ and the mixture was refluxed overnight. Then, the resulting yellow solid was filtered off and washed with water and cold ether. From the resulting solution after filtration, yellow crystals were isolated after slow evaporation of ethanol. (192 mg, 76\%). Anal. Calc. (\%) for $\mathrm{C}_{9} \mathrm{H}_{11} \mathrm{Cl}_{2} \mathrm{~N}_{3} \mathrm{PtS} \cdot \mathrm{C}_{2} \mathrm{H}_{6} \mathrm{O}$ : C, 26.13; $\mathrm{H}, 3.36 ; \mathrm{N}, 8.31 ; \mathrm{S}, 6.34 \%$. Found: $\mathrm{C}, 26.04 ; \mathrm{H}, 3.25$; $\mathrm{N}, 8.41$; S, $6.53 \%$. IR (KBr): $v(\mathrm{NH}) 3262,3225,3173,3126, v(\mathrm{C}=\mathrm{N}) 1631$, (thiazine ring vibrations) 954, 794, 769, 735, 631, 594, (pyridine ring vibrations) 1599, 1527, 1479, 1421, 1349 , 1318, 1268, 1100 (metal-ligand vibrations) 259, 252, 243, $232 \mathrm{~cm}^{-1} .{ }^{1} \mathrm{H}$ NMR $(500 \mathrm{MHz}$, DMF- $\left.d_{7}\right) \delta 11.20(\mathrm{~s}, 1 \mathrm{H}), 9.01(\mathrm{~d}, J=6.3, \mathrm{~Hz}, 1 \mathrm{H}), 8.06(\mathrm{t}, J=7.6 \mathrm{~Hz}, 1 \mathrm{H}), 7.39(\mathrm{~d}, J=8.2 \mathrm{~Hz}$, $1 \mathrm{H}), 7.23(\mathrm{t}, J=6.7 \mathrm{~Hz}, 1 \mathrm{H}), 4.02(\mathrm{t}, J=5.5 \mathrm{~Hz}, 2 \mathrm{H}), 3.30(\mathrm{t}, J=6.9 \mathrm{~Hz}, 2 \mathrm{H}), 2.09(\mathrm{~m}, 2 \mathrm{H}) .{ }^{13} \mathrm{C}$ NMR (126 MHz, DMF) $\delta 156.0,150.6,148.7,140.6,120.5,114.2,52.4,27.2,23.4$. 


\subsection{Synthesis of $\left[\mathrm{PdCl}_{2}(\mathrm{PyTz})\right] \cdot \mathrm{C}_{2} \mathrm{H}_{6} \mathrm{O}(\mathrm{PdPyTz})$}

A solution of PyTz $(96.5 \mathrm{mg}, 0.5 \mathrm{mmol})$ in ethanol $(30 \mathrm{~mL})$ was added dropwise to a solution of $\mathrm{Na}_{2}\left[\mathrm{PdCl}_{4}\right] \cdot \mathrm{H}_{2} \mathrm{O}(156 \mathrm{mg}, 0.5 \mathrm{mmol})$ in ethanol $(40 \mathrm{~mL})$, and the mixture was refluxed overnight. Then, the resulting orange solid was filtered off and washed with water and cold ether. From the resulting solution after filtration, orange crystals were isolated after slow evaporation of ethanol. (182.2 mg, 87\%). Anal. Calc. (\%) for $\mathrm{C}_{9} \mathrm{H}_{11} \mathrm{Cl}_{2} \mathrm{~N}_{3}$ PdS $0.75 \mathrm{C}_{2} \mathrm{H}_{6} \mathrm{O} \cdot 0.75 \mathrm{H}_{2} \mathrm{O}: \mathrm{C}, 30.10 ; \mathrm{H}, 4.06 ; \mathrm{N}, 10.03 ; \mathrm{S}, 7.66 \%$. Found: $\mathrm{C}, 29.82 ;$ $\mathrm{H}, 3.72 ; \mathrm{N}, 9.81$; $\mathrm{S}, 7.44 \%$. IR (KBr): $v(\mathrm{NH}) 3261,3226,3175,3124, v(\mathrm{C}=\mathrm{N}) 1629$, (thiazine ring vibrations) $952,795,767,734,630,595$, (pyridine ring vibrations) 1599, 1526, 1475, 1420, 1351, 1315, 1095 (metal-ligand vibrations) $254,242,233 \mathrm{~cm}^{-1} .{ }^{1} \mathrm{H}$ NMR (500 MHz, DMF- $d_{7}$ ) $\delta 11.33(\mathrm{~s}, 1 \mathrm{H}), 8.75(\mathrm{~d}, J=5.9 \mathrm{~Hz}, 1 \mathrm{H}), 8.06(\mathrm{t}, J=7.6 \mathrm{~Hz}, 1 \mathrm{H}), 7.41(\mathrm{~d}, J=8.3 \mathrm{~Hz}, 1 \mathrm{H}), 7.29$ $(\mathrm{t}, J=6.6 \mathrm{~Hz}, 1 \mathrm{H}), 3.85(\mathrm{t}, J=5.4 \mathrm{~Hz}, 2 \mathrm{H}), 3.29(\mathrm{t}, J=6.8 \mathrm{~Hz}, 2 \mathrm{H}), 2.05(\mathrm{~m}, 2 \mathrm{H}) .{ }^{13} \mathrm{C}$ NMR (126 MHz, DMF) \& 162.1, 156.78, 151.1, 148.2, 141.5, 120.3, 114.3, 51.9, 27.2, 23.2.

\subsection{Isolation of Single Crystals of PyTzHCl-2 $\mathrm{H}_{2} \mathrm{O}$}

2-(2-pyridyl)iminotetrahydro-1,3-thiazinehydrochloride-water (1/2) $\left(\mathrm{PyTzHCl}_{2} \cdot \mathrm{H}_{2} \mathrm{O}\right)$ was synthetized according to a reported method [24]. However, the crystalline structure of this compound has not been previously reported in the literature. Therefore, in order to obtain single crystals of $\mathrm{PyTzHCl} \cdot 2 \mathrm{H}_{2} \mathrm{O}$, the solid obtained from the synthesis was recrystallized by slow diffusion of $n$-hexane in a solution of $\mathrm{PyTzHCl} \cdot 2 \mathrm{H}_{2} \mathrm{O}$ in ethanol $96 \%$, which afforded colourless single crystals of PyTHCl. $2 \mathrm{H}_{2} \mathrm{O}$ after 10 days. Anal. Calc. (\%) for $\mathrm{C}_{9} \mathrm{H}_{16} \mathrm{ClN}_{3} \mathrm{O}_{2} \mathrm{~S}: \mathrm{C}, 40.83 ; \mathrm{H}, 6.29 ; \mathrm{N}, 15.81 ; \mathrm{S}, 11.56 \%$. Found: $\mathrm{C}, 40.67 ; \mathrm{H}, 6.02 ; \mathrm{N}, 15.80$; $\mathrm{S}, 12.07 \%$.

\subsection{X-ray Diffraction}

Crystals of the precursor PyTzHCl$\cdot 2 \mathrm{H}_{2} \mathrm{O}$ and the complexes PtPyTz and PdPyTz were obtained as mentioned above. Crystal, structure determination and refinement data are reported in Table 4.

Data were collected on a Bruker Kappa APEXII CCD diffractometer, using graphitemonochromated Mo-K $\alpha$ radiation $(\lambda=0.71073 \AA)$. All data were corrected for Lorentz and polarization effects, while absorption corrections were performed by means of SADABS [42] program. The structures were solved by direct methods and subsequent Fourier differences using the SHELXS-14 [43] program and refined by full-matrix least-squares on F2 with SHELXL-18 [44], included in WINGX [45] package, assuming anisotropic displacement parameters for non-hydrogen atoms. All hydrogen atoms attached to carbon or nitrogen atoms were positioned geometrically, with $U_{\text {iso }}$ values derived from $U_{\text {eq }}$ values of the corresponding carbon and nitrogen atoms. Hydrogen atoms of the water molecules were detected by Fourier differences and were refined with isotropic temperature factors. Crystallographic data for precursor PyTzHCl$\cdot 2 \mathrm{H}_{2} \mathrm{O}$ and for complexes PtPyTz and PdPyTz were deposited at the CCDC (Cambridge Crystallographic Data Center, Cambridge, UK) with CCDC numbers 2055561, 2055559 and 2055560, respectively. 
Table 4. Crystal data, data collection and refinement details for PyTzHCl-2 $\mathrm{H}_{2} \mathrm{O}, \mathrm{PtPyTz}$ and PdPyTz.

\begin{tabular}{|c|c|c|c|}
\hline & $\mathrm{PyTzHCl} \cdot 2 \mathrm{H}_{2} \mathrm{O}$ & PtPyTz & PdPyTz \\
\hline Crystal shape & Plate & Plate & Prism \\
\hline Colour & Colourless & Yellow & Orange \\
\hline Size $(\mathrm{mm})$ & $0.59 \times 0.30 \times 0.11$ & $0.17 \times 0.13 \times 0.07$ & $0.36 \times 0.33 \times 0.14$ \\
\hline Chemical formula & $\mathrm{C}_{9} \mathrm{H}_{16} \mathrm{~N}_{3} \mathrm{OS}$ & $\mathrm{C}_{11} \mathrm{H}_{17} \mathrm{Cl}_{2} \mathrm{~N}_{3} \mathrm{OPtS}$ & $\mathrm{C}_{11} \mathrm{H}_{17} \mathrm{Cl}_{2} \mathrm{~N}_{3} \mathrm{OPdS}$ \\
\hline Formula weight & 265.76 & 505.32 & 416.63 \\
\hline Crystal system & Triclinic & Monoclinic & Monoclinic \\
\hline Space group & P-1 & $\mathrm{P} 2{ }_{1} / \mathrm{c}$ & $\mathrm{P} 2{ }_{1} / \mathrm{c}$ \\
\hline \multicolumn{4}{|l|}{ Unit cell dimensions } \\
\hline a $(\AA)$ & $6.9676(2)$ & $12.6205(4)$ & $12.6048(4)$ \\
\hline b $(\AA)$ & $9.5773(3)$ & $9.0616(2)$ & $9.0445(3)$ \\
\hline$c(\AA)$ & $9.5927(3)$ & $13.8145(4)$ & $13.8167(5)$ \\
\hline$\alpha\left(^{\circ}\right)$ & $96.001(2)$ & & \\
\hline$\beta\left({ }^{\circ}\right)$ & $97.830(2)$ & $109.540(2)$ & $109.575(2)$ \\
\hline$\gamma\left({ }^{\circ}\right)$ & $101.185(2)$ & & \\
\hline Cell volume $\left(\AA^{3}\right)$ & $616.44(4)$ & $1488.8(7)$ & 1484.12(9) \\
\hline Z & 2 & 4 & 4 \\
\hline Dcalc $\left(\mathrm{g} \mathrm{cm}^{-3}\right)$ & 1.432 & 2.254 & 1.865 \\
\hline$\mu\left(\mathrm{mm}^{-1}\right)$ & 0.47 & 9.918 & 1.746 \\
\hline $\mathrm{F}(000)$ & 280 & 960 & 832 \\
\hline$\theta$ range & $2.16-35.57$ & $2.74-32.26$ & $2.74-30.29$ \\
\hline & $-11 \leq \mathrm{h} \leq 11$ & $-19 \leq \mathrm{h} \leq 19$ & $-19 \leq \mathrm{h} \leq 19$ \\
\hline Index ranges & $-16 \leq \mathrm{k} \leq 16$ & $-13 \leq \mathrm{k} \leq 13$ & $-13 \leq \mathrm{k} \leq 13$ \\
\hline & $-16 \leq 1 \leq 16$ & $-21 \leq 1 \leq 21$ & $-21 \leq 1 \leq 21$ \\
\hline Temperature $(\mathrm{K})$ & 100 & 100 & 100 \\
\hline Independent reflections & 6033 & 5660 & 5649 \\
\hline Observed reflections & $5254[\mathrm{~F}>4.0 \sigma(\mathrm{F})]$ & $4407[\mathrm{~F}>4.0 \sigma(\mathrm{F})]$ & $4746[\mathrm{~F}>4.0 \sigma(\mathrm{F})]$ \\
\hline No. of refined parameters & 195 & 180 & 181 \\
\hline $\mathrm{R}[\mathrm{F}>4.0 \sigma(\mathrm{F})]$ & 0.042 & 0.030 & 0.027 \\
\hline $\mathrm{wR}[\mathrm{F}>4.0 \sigma(\mathrm{F})]$ & 0.125 & 0.044 & 0.051 \\
\hline GOF & 1.052 & 0.993 & 1.021 \\
\hline$\rho \max , \rho \min \left(\mathrm{e} \AA^{-3}\right)$ & $0.622,-1,210$ & $1.604,-1.464$ & $0.545,1.034$ \\
\hline
\end{tabular}

\subsection{Cell Culture and Treatments}

Cells were grown in DMEM (HeLa), McCoy's 5a (SK-OV-3), RPMI-1640 (U-937 and HL-60) or DMEM F-12 (MCF10A) medium. The media were supplemented with $2 \mathrm{mM}$ L-glutamine, $10 \%$ heat-inactivated FBS, $100 \mathrm{U} / \mathrm{mL}$ penicillin, and $10 \mu \mathrm{g} / \mathrm{mL}$ streptomycin, except for DMEM F-12, which was supplemented with $5 \%$ horse serum, $0.5 \mu \mathrm{g} / \mathrm{mL}$ hydrocortisone, $10 \mu \mathrm{g} / \mathrm{mL}$ insulin, $20 \mathrm{ng} / \mathrm{mL}$ EGF, $100 \mathrm{ng} / \mathrm{mL}$ cholera toxin, $100 \mathrm{U} / \mathrm{mL}$ penicillin, and $10 \mu \mathrm{g} / \mathrm{mL}$ streptomycin. Cells were cultured under a humidified atmosphere containing $95 \%$ air and $5 \% \mathrm{CO} 2$ at $37{ }^{\circ} \mathrm{C}$. Cells were usually plated at a density of $7 \times 10^{5}$ cells $/ \mathrm{mL}$ (HeLa, SK-OV-3 and MCF10A) or $3 \times 10^{5}$ cells $/ \mathrm{mL}$ (HL-60 and U-937) into $25 \mathrm{~cm}^{2}$ culture flasks and the viability was routinely kept at $>95 \%$ as assayed by the Trypan-blue exclusion method. Cells were treated with the free ligand (PyTz), its Pt(II) and $\mathrm{Pd}(\mathrm{II})$ complexes (PtPyTz and PdPyTz) or vehicle for $24 \mathrm{~h}$ at the indicated concentrations. DMF was used as vehicle and its final concentration did not exceed $0.5 \%(v / v)$.

\subsection{In Vitro Cytotoxicity Assay}

The cytotoxic effects of the different compounds were evaluated on all four cell lines by means of the CellTiter 96 AQueous One Solution Cell Proliferation Assay, which is based on the reduction of an MTS tetrazolium compound. Cells were seeded in 96-well plates at a density of $8 \times 10^{3}$ cells /well (HeLa and MCF10A), $6 \times 10^{3}$ cells/well (SK-OV-3), $1.5 \times 10^{4}$ cells/well (U-937) or $2.5 \times 10^{4}$ cells/well (HL-60). After treating cultures for $24 \mathrm{~h}$, assays were performed by adding $10 \mu \mathrm{L}$ of the CellTiter 96 AQueous One Solution Reagent directly to culture wells, incubating for $15 \mathrm{~min}$ (HeLa), $30 \mathrm{~min}$ (SK-OV-3), $1 \mathrm{~h}$ (U-937 and MCF10A) or $2 \mathrm{~h}$ (HL-60) at $37^{\circ} \mathrm{C}$, and then recording absorbance on a microplate reader 
(Infinite M200; Tecan Gorup Ltd., Männedorf, Switzerland) at both a test wavelength of $490 \mathrm{~nm}$ and a reference wavelength of $650 \mathrm{~nm}$ to subtract background. All analyses were run in triplicate. The cell viability was calculated as percentage of control values (untreated samples).

\subsection{Statistical Analysis}

Data are presented as mean \pm standard deviation (SD). To compare the different treatments, statistical significance was calculated by one-way analysis of variance (ANOVA) followed by Tukey's test. IC $_{50}$ values obtained from the dose-response curve of each compound were calculated by fitting the curve to the data using nonlinear regression to generate a four-parameter sigmoid dose-response equation. $p<0.05$ was considered to indicate a statistically significant difference. The statistics software used was GraphPad Prism 7.04 for Windows.

\section{Conclusions}

New platinum(II) and palladium(II) complexes containing a thiazine-pyridine derivative ligand, PyTz, were prepared and characterized. It should be noted that PdPyTz is the first crystal structure that is described with $\mathrm{Pd}$ (II) linked to a nitrogen atom belonging to a 1,3-thiazine heterocycle. With regard to the antiproliferative activity, our findings show that the newly developed chemotherapeutic agent PtPyTz has greater cytotoxic activity than the PyTz-containing Pd(II) complex and the PyTz free ligand in all four human tumor cell lines tested, being more effective in leukemic cell lines than in those derived from solid tumors and non-tumor cell line. This suggests that the cytotoxic effect of these complexes is modulated by the central metal.

Supplementary Materials: The following materials are available online at https://www.mdpi. com/article/10.3390/ph14050395/s1. Figure S1: Structural parameters of $\left\{\left[\left(\mathrm{H}_{2} \mathrm{O}\right)_{5} \mathrm{Cl}_{3}\right]^{3-}\right\}_{\mathrm{n}}$ tapes in PyTzHCl $2 \mathrm{H}_{2} \mathrm{O}$ title; Figure S2: Supramolecular arrangement in PtPyTz stabilized by intramolecular hydrogen-bonds; Figure S3: Supramolecular arrangement in PdPyTz stabilized by intramolecular hydrogen-bonds; Table S1: ${ }^{1} \mathrm{H}$ NMR spectral data for PyTz and its Pt (II) and Pd(II) complexes in DMF-d $\mathrm{d}_{7}$ solvent; Figure S4: ${ }^{1} \mathrm{H}$ NMR spectrum of PyTz in DMF- $\mathrm{d}_{7}$; Figure S5: ${ }^{13} \mathrm{C}$ NMR spectrum of PyTz in DMF- $\mathrm{d}_{7}$; Figure S6: ${ }^{1} \mathrm{H}$ NMR spectrum of PtPyTz in DMF- $\mathrm{d}_{7}$; Figure S7: ${ }^{13} \mathrm{C}$ NMR spectrum of PtPyTz in DMF-d $\mathrm{d}_{7}$; Figure S8: ${ }^{1} \mathrm{H}$ NMR spectrum of PdPyTz in DMF-d $\mathrm{d}_{7}$; Figure S9: ${ }^{13} \mathrm{C}$ NMR spectrum of PdPyTz in DMF- $\mathrm{d}_{7}$; Figure S10. ${ }^{1} \mathrm{H}$ NMR spectrum of PyTz in $\mathrm{D}_{2} \mathrm{O}: \mathrm{DMF}-\mathrm{d}_{7}$ (11:1 ratio) after preparation (red), $1 \mathrm{~h}$ (green), $6 \mathrm{~h}$ (blue), $24 \mathrm{~h}$ (purple); Figure S11. ${ }^{1} \mathrm{H}$ NMR spectrum of PtPyTz in $\mathrm{D}_{2} \mathrm{O}: \mathrm{DMF}-\mathrm{d}_{7}$ (11:1 ratio) after preparation (red), $1 \mathrm{~h}$ (green), $6 \mathrm{~h}$ (blue), $24 \mathrm{~h}$ (purple); Figure S12. ${ }^{1} \mathrm{H}$ NMR spectrum of PyTz in $\mathrm{D}_{2} \mathrm{O}: \mathrm{DMF}_{7} \mathrm{~d}_{7}$ (11:1 ratio) after preparation (red), $1 \mathrm{~h}$ (green), $6 \mathrm{~h}$ (blue), $24 \mathrm{~h}$ (purple); Figure S13: FTIR spectrum of PtPyTz between 4000-400 $\mathrm{cm}^{-1}$; Figure S14: FTIR spectrum of PtPyTz between $500-150 \mathrm{~cm}^{-1}$; Figure S15: FTIR spectrum of PdPyTz between 4000-400 $\mathrm{cm}^{-1}$; Figure S16: FTIR spectrum of PdPyTz between $500-150 \mathrm{~cm}^{-1}$; Table S2: ADME properties factor of the synthesized compounds.

Author Contributions: Conceptualization, F.L.-G.; methodology, S.G.-T., J.E., F.L.-G.; formal analysis, S.G.-T., J.E., F.L.-G., E.V.-Z.; investigation, S.G.-T., J.E., F.L.-G., E.V.-Z.; data curation, S.G.-T., J.E., F.L.G., E.V.-Z.; writing—original draft preparation, S.G.-T., J.E., F.L.-G., J.A.P., A.B.R., E.V.-Z.; writingreview and editing, S.G.-T., J.E., F.L.-G., J.A.P., A.B.R., E.V.-Z.; visualization, S.G.-T., J.E., F.L.-G., J.A.P., A.B.R., E.V.-Z.; supervision, F.L.-G., J.A.P., A.B.R., E.V.-Z.; project administration, F.L.-G., J.A.P.; funding acquisition, F.L.-G., J.A.P. All authors have read and agreed to the published version of the manuscript.

Funding: This work was supported by Junta de Extremadura grants (ref. GR18040, GR18062 and IB18013). J. Espino holds a research post-doctoral fellowship from Junta de Extremadura (ref. TA18002).

Institutional Review Board Statement: Not applicable.

Informed Consent Statement: Not applicable. 
Data Availability Statement: Data is contained within the article or supplementary material. Anyway, the datasets generated during the current study are available from the corresponding author on request.

Acknowledgments: The authors appreciate the technical and human support provided by the facility of Elemental and Molecular Analysis Service of SAIUEx (financed by UEx, Junta de Extremadura, MICINN, FEDER, and FSE). X-ray intensity measurements were performed at the Unidade de Raios X. RIAIDT, University of Santiago de Compostela. Spain.

Conflicts of Interest: The authors declare no conflict of interest. The funders had no role in the design of the study; in the collection, analyses, or interpretation of data; in the writing of the manuscript, or in the decision to publish the results.

\section{References}

1. Arenaza-Corona, A.; Couce-Fortúnez, M.D.; de Blas, A.; Morales-Morales, D.; Santillan, R.; Höpfl, H.; Rodríguez-Blas, T.; Barba, V. Further Approaches in the Design of Antitumor Agents with Response to Cell Resistance: Looking toward Aza Crown Ether-dtc Complexes. Inorg. Chem. 2020, 59, 15120-15134. [CrossRef]

2. Fernández-Delgado, E.; de la Cruz-Martínez, F.; Galán, C.; Franco, L.; Espino, J.; Viñuelas-Zahínos, E.; Luna-Giles, F.; Bejarano, I. $\mathrm{Pt}(\mathrm{II})$ and $\mathrm{Pd}(\mathrm{II})$ complexes with a thiazoline derivative ligand: Synthesis, structural characterization, antiproliferative activity and evaluation of pro-apoptotic ability in tumor cell lines HT-29 and U-937. J. Inorg. Biochem. 2020, 202, 110870. [CrossRef] [PubMed]

3. Lazarević, T.; Rilak, A.; Bugarčić, Ž.D. Platinum, palladium, gold and ruthenium complexes as anticancer agents: Current clinical uses, cytotoxicity studies and future perspectives. Eur. J. Med. Chem. 2017, 142, 8-31. [CrossRef]

4. Pasetto, L.M.; D'Andrea, M.R.; Brandes, A.A.; Rossi, E.; Monfardini, S. The development of platinum compounds and their possible combination. Crit. Rev. Oncol. Hematol. 2006, 60, 59-75. [CrossRef] [PubMed]

5. Giaccone, G. Clinical perspectives on platinum resistance. Drugs 2000, 59, 9-17. [CrossRef] [PubMed]

6. Kelland, L. The resurgence of platinum-based cancer chemotherapy. Nat. Rev. Cancer 2007, 7, 573-584. [CrossRef]

7. Pariente, R.; Pariente, J.A.; Rodríguez, A.B.; Espino, J. Melatonin sensitizes human cervical cancer HeLa cells to cisplatin-induced cytotoxicity and apoptosis: Effects on oxidative stress and DNA fragmentation. J. Pineal Res. 2016, 60, 55-64. [CrossRef]

8. Galluzzi, L.; Senovilla, L.; Vitale, I.; Michels, J.; Martins, I.; Kepp, O.; Castedo, M.; Kroemer, G. Molecular mechanisms of cisplatin resistance. Oncogene 2012, 31, 1869-1883. [CrossRef]

9. Shen, D.W.; Pouliot, L.M.; Hall, M.D.; Gottesman, M.M. Cisplatin resistance: A cellular self-defense mechanism resulting from multiple epigenetic and genetic changes. Pharmacol. Rev. 2012, 64, 706-721. [CrossRef]

10. Cvitkovic, E. Cumulative toxicities from cisplatin therapy and current cytoprotective measures. Cancer Treat. Rev. 1998, 24, 265-281. [CrossRef]

11. Screnci, D.; McKeage, M.J. Platinum neurotoxicity: Clinical profiles, experimental models and neuroprotective approaches. J. Inorg. Biochem. 1999, 77, 105-110. [CrossRef]

12. Kasturi, J.; Palla, P.R.; Bakshi, V.; Boggula, N. Journal of Drug Delivery and Therapeutics Non-steroidal anti-inflammatory drugs: An overview. J. Drug Deliv. Ther. 2019, 9, 442-448.

13. Ali, I.; Wani, W.A.; Saleem, K.; Haque, A. Platinum Compounds: A Hope for Future Cancer Chemotherapy. Anticancer. Agents Med. Chem. 2013, 13, 296-306. [CrossRef]

14. Kapdi, A.R.; Fairlamb, I.J.S. Anti-cancer palladium complexes: A focus on PdX2L2, palladacycles and related complexes. Chem. Soc. Rev. 2014, 43, 4751-4777. [CrossRef]

15. Coskun, M.D.; Ari, F.; Oral, A.Y.; Sarimahmut, M.; Kutlu, H.M.; Yilmaz, V.T.; Ulukaya, E. Promising anti-growth effects of palladium(II) saccharinate complex of terpyridine by inducing apoptosis on transformed fibroblasts in vitro. Bioorg. Med. Chem. 2013, 21, 4698-4705. [CrossRef]

16. Bugarčić, Ž.D.; Bogojeski, J.; van Eldik, R. Kinetics, mechanism and equilibrium studies on the substitution reactions of Pd(II) in reference to Pt(II) complexes with bio-molecules. Coord. Chem. Rev. 2015, 292, 91-106. [CrossRef]

17. Qin, Q.P.; Zou, B.Q.; Tan, M.X.; Luo, D.M.; Wang, Z.F.; Wang, S.L.; Liu, Y.C. High in vitro anticancer activity of a dinuclear palladium(II) complex with a 2-phenylpyridine ligand. Inorg. Chem. Commun. 2018, 96, 106-110. [CrossRef]

18. Ćoćić, D.; Jovanović, S.; Nišavić, M.; Baskić, D.; Todorović, D.; Popović, S.; Bugarčić, Ž.D.; Petrović, B. New dinuclear palladium(II) complexes: Studies of the nucleophilic substitution reactions, DNA/BSA interactions and cytotoxic activity. J. Inorg. Biochem. 2017, 175, 67-79. [CrossRef]

19. Espino, J.; Fernández-Delgado, E.; Estirado, S.; de la Cruz-Martinez, F.; Villa-Carballar, S.; Viñuelas-Zahínos, E.; Luna-Giles, F.; Pariente, J.A. Synthesis and structure of a new thiazoline-based palladium(II) complex that promotes cytotoxicity and apoptosis of human promyelocytic leukemia HL-60 cells. Sci. Rep. 2020, 10, 1-16.

20. Orlova, M.A.; Trofimova, T.P.; Filimonova, M.V.; Proshin, A.N.; Zaitsev, D.A. Effect of the thiazine and thiourea derivatives as NO-synthase effectors on the survival of leukemic cells. Russ. Chem. Bull. 2013, 62, 1111-1114. [CrossRef] 
21. Bruno, I.J.; Cole, J.C.; Edgington, P.R.; Kessler, M.; Macrae, C.F.; McCabe, P.; Pearson, J.; Taylor, R. New software for searching the Cambridge Structural Database and visualizing crystal structures. Acta Crystallogr. Sect. B Struct. Sci. 2002, 58, 389-397. [CrossRef]

22. Zhang, J.Q.; Li, K.; Cong, Y.W.; Pu, S.P.; Zhu, H.Y.; Xie, X.G.; Jin, Y.; Lin, J. Preparation, characterisation and bioactivity evaluation of the inclusion complex formed between picoplatin and $\gamma$-cyclodextrin. Carbohydr. Res. 2014, 396, 54-61. [CrossRef] [PubMed]

23. Barros-García, F.J.; Bernalte-García, A.; Higes-Rolando, F.J.; Luna-Giles, F.; Pedrero-Marín, R. X-ray and spectroscopic characterisation of cobalt(III) and nickel(II) complexes with 2-(2-pyridyl)iminotetrahydro-1,3-thiazine hydrochloride-water (1/2) (PyTzHCl-2H2O) in the solid state and study of its interaction with cobalt(II) and nickel(II) in aqu. Polyhedron 2004, 23, 1453-1460. [CrossRef]

24. Bernalte-Garcia, A.; García-Barros, F.J.; Higes-Rolando, F.J.; Luna-Giles, F.; Pedrero-Marín, R. Synthesis and physic-chemical properties of a copper(II) complex with 2-(2-pyridyl)iminotetrahydro-1,3-thiazine hydrochloride-water (1/2) (PyTzHCl-2H2O). Crystal structure of PyTz and [ $\{\mathrm{CuCl}(\mathrm{PyTz})\} 2(\mu-\mathrm{Cl}) 2]$. J. Inorg. Biochem. 2004, 98, 15-23. [CrossRef]

25. García-Cuesta, M.C.; Lozano, A.M.; Meléndez-Martínez, J.J.; Luna-Giles, F.; Ortiz, A.L.; González-Méndez, L.M.; Cumbrera, F.L. Structure determination of nitrato-kO-bis[2-(2-pyridyl-kN)amino-5,6-dihydro-4H-1,3-thiazine-kN]copper(II) nitrate via molecular modelling coupled with X-ray powder diffractometry. J. Appl. Crystallogr. 2004, 37, 993-999. [CrossRef]

26. Allen, F.H.; Kennard, O.; Watson, D.G.; Brammer, L.; Orpen, A.G.; Taylor, R. Tables of bond lengths determined by X-ray and neutron diffraction. Part 1. Bond lengths in organic compounds. J. Chem. Soc. Perkin Trans. 1987, 2, S1-S19. [CrossRef]

27. Fateley, W.G.; Dollish, F.R.; McDevitt, N.T.; Bentley, F.F. Infrared and Raman Selection Rules for Molecular and Lattice Vibrations: The Correlation Method; Wiley-Interscience: New York, NY, USA, 1972.

28. Nakamoto, K. Infrared and Raman Spectra of Inorganic and Coordination Compounds, 5th ed.; John Wiley \& Sons: New York, NY, USA, 1997; ISBN 9780470027325.

29. Ferraro, J.R. Low-Frequency Vibrations of Inorganic and Coordination Compounds; Springer Plenum Press: New York, NY, USA, 1971; ISBN 978-1-4684-1811-8.

30. Nakamoto, K.; Mccarthy, P.J.; Fujita, J.; Condrate, R.A.; Behnke, G.T. Infrared Studies of Ligand-Ligand Interaction in Dihalogenodiammineplatinum(II) Complexes. Inorg. Chem. 1965, 4, 36-43. [CrossRef]

31. Dehand, J.; Jordanov, J. Complexes of $\mathrm{Pt}(\mathrm{II}), \mathrm{Pd}(\mathrm{II}), \mathrm{Rh}(\mathrm{I})$ and $\mathrm{Rh}(\mathrm{III})$ with nitrogen and sulfur-containing heterocyclic ligands of biological interest. Synthesis, characterization and influence of pH. Inorg. Chim. Acta 1976, 17, 37-44. [CrossRef]

32. Belluco, U.; Benetollo, F.; Bertani, R.; Bombieri, G.; Michelin, R.A.; Mozzon, M.; Pombeiro, A.J.L.; Guedes da Silva, F.C. Stereochemical investigation of the addition of primary and secondary aliphatic amines to the nitrile complexes cis- and trans-[PtCl2(NCMe)2]. X-ray structures of the amidine complexes trans-[Pt(NH2Pri $2\{\mathrm{Z}-\mathrm{N}(\mathrm{H})=\mathrm{C}(\mathrm{NHPr} \mathrm{i}) \mathrm{Me}\}] \mathrm{Cl} 2 \cdot 4 \mathrm{H} 2 \mathrm{O}$ and trans-[PtCl2(NCMe). Inorg. Chim. Acta 2002, 330, 229-239. [CrossRef]

33. Durig, J.R.; Layton, R.; Sink, D.W.; Mitchell, B.R. Far infrared spectra of palladium compounds-I. The influence of ligands upon the palladium chloride stretching frequency. Spectrochim. Acta 1965, 21, 1367-1378. [CrossRef]

34. Daina, A.; Michielin, O.; Zoete, V. SwissADME: A free web tool to evaluate pharmacokinetics, drug-likeness and medicinal chemistry friendliness of small molecules. Sci. Rep. 2017, 7, 1-13. [CrossRef]

35. Lipinski, C.A.; Lombardo, F.; Dominy, B.W.; Feeney, P.J. Experimental and computational approaches to estimate solubility and permeability in drug discovery and development settings. Adv. Drug Deliv. Rev. 2001, 46, 3-26. [CrossRef]

36. Baell, J.B.; Holloway, G.A. New Substructure Filters for Removal of Pan Assay Interference Compounds (PAINS) from Screening Libraries and for Their Exclusion in Bioassays. J. Med. Chem. 2010, 53, 2719. [CrossRef] [PubMed]

37. Keter, F.K.; Kanyanda, S.; Lyantagaye, S.S.L.; Darkwa, J.; Rees, D.J.G.; Meyer, M. In vitro evaluation of dichlorobis(pyrazole)palladium(II) and dichloro-bis(pyrazole)platinum(II) complexes as anticancer agents. Cancer Chemother. Pharmacol. 2008, 63, 127-138. [CrossRef] [PubMed]

38. Miklášová, N.; Fischer-Fodor, E.; Lönnecke, P.; Tomuleasa, C.I.; Virag, P.; Perde Schrepler, M.; Mikláš, R.; Silaghi Dumitrescu, L.; Hey-Hawkins, E. Antiproliferative effect of novel platinum(II) and palladium(II) complexes on hepatic tumor stem cells in vitro. Eur. J. Med. Chem. 2012, 49, 41-47. [CrossRef] [PubMed]

39. Ćoćić, D.; Jovanović, S.; Radisavljević, S.; Korzekwa, J.; Scheurer, A.; Puchta, R.; Baskić, D.; Todorović, D.; Popović, S.; Matić, S.; et al. New monofunctional platinum(II) and palladium(II) complexes: Studies of the nucleophilic substitution reactions, DNA/BSA interaction, and cytotoxic activity. J. Inorg. Biochem. 2018, 189, 91-102. [CrossRef] [PubMed]

40. Icsel, C.; Yilmaz, V.T.; Aygun, M.; Cevatemre, B.; Alper, P.; Ulukaya, E. Palladium(ii) and platinum(ii) saccharinate complexes with bis(diphenylphosphino)methane/ethane: Synthesis, S-phase arrest and ROS-mediated apoptosis in human colon cancer cells. Dalt. Trans. 2018, 47, 11397-11410. [CrossRef] [PubMed]

41. Price, J.H.; Williamson, A.N.; Schramm, R.F.; Wayland, B.B. Palladium(II) and Platinum(II) Alkyl Sulfoxide Complexes. Examples of Sulfur-Bonded, Mixed Sulfur- and Oxygen-Bonded, and Totally Oxygen-Bonded Complexes. Inorg. Chem. 1972, 11, 1280-1284. [CrossRef]

42. Bruker, AXS Inc. SADABS; Bruker: Madison, WI, USA, 2012.

43. Sheldrick, M. SHELXS-14, Program for Crystal Structures Solution; University of Göttingen: Göttingen, Germany, 2014.

44. Sheldrick, G.M. Crystal structure refinement with SHELXL. Acta Crystallogr. Sect. C 2015, 71, 3-8. [CrossRef]

45. Farrugia, L.J. WinGX and ORTEP for Windows: An update. J. Appl. Crystallogr. 2012, 45, 849-854. [CrossRef] 